\title{
Seasonal cycles of fluorescent biological aerosol particles in boreal and semi-arid forests of Finland and Colorado
}

\author{
C. J. Schumacher ${ }^{1}$, C. Pöhlker ${ }^{2}$, P. Aalto ${ }^{3}$, V. Hiltunen ${ }^{3}$, T. Petäjä̈ ${ }^{3}$, M. Kulmala ${ }^{3}$, U. Pöschl ${ }^{2}$, and J. A. Huffman ${ }^{1,2}$ \\ ${ }^{1}$ Department of Chemistry and Biochemistry, University of Denver, Denver, Colorado, USA \\ ${ }^{2}$ Departments of Biogeochemistry and Multiphase Chemistry, Max Planck Institute for Chemistry, Mainz, Germany \\ ${ }^{3}$ Department of Physics, University of Helsinki, Helsinki, Finland
}

Correspondence to: J. A. Huffman (alex.huffman@du.edu)

Received: 6 June 2013 - Published in Atmos. Chem. Phys. Discuss.: 27 June 2013

Revised: 30 October 2013 - Accepted: 6 November 2013 - Published: 11 December 2013

\begin{abstract}
Biological aerosol particles have become increasingly important for atmospheric study, but continuous measurements at high time and size resolution have not been available until recently. Here we report seasonal cycles of fluorescent biological aerosol particles (FBAP) from the boreal forest in Hyytiälä, Finland (18 months) and the semi-arid Manitou Experimental Forest, Colorado (10 months). FBAP at both locations were observed to be highest in summer and lowest in winter, increasing by factors of 12 and 5 between these seasons, respectively. In addition to the low temperatures and reduced sunlight during winter, we suggest that snow cover inhibited FBAP release from local terrestrial surfaces and that more extensive snow cover at the Finland site contributed to lower winter FBAP concentrations. Average size distributions at each site exhibited peaks between 1.5 and $6 \mu \mathrm{m}$ in aerodynamic diameter. The Finland site consistently showed a dominant, narrow FBAP peak at $\sim 3 \mu \mathrm{m}$ in addition to discreet modes at $\sim 1.5$ and $\sim 5 \mu \mathrm{m}$, whereas the Colorado site showed broader peaks at 1.5 and $5 \mu \mathrm{m}$, suggesting different modes of biological particles at the two sites. FBAP concentrations in both locations were shown to correlate with daily patterns of relative humidity $(\mathrm{RH})$ during each season. Also during summer at each site, average FBAP concentration scaled with RH, but at the Finland site RH values above $\sim 82 \%$ led to a significant decrease in FBAP concentration. We hypothesize that this is due to dew formation that inhibits bioparticle release. Lastly we show that rain during summer at each location led to pronounced increases in both fluorescent and total particle concentrations with FBAP peak particle size at $\sim 2 \mu \mathrm{m}$ and concentration scaling with rain intensity. We suggest that these particles are primarily
\end{abstract}

fungal spores and other bioparticles lofted from splashing of rain droplets hitting soil and leaf surfaces. During the summer at the Colorado site we consistently observed a mode of $\sim 4 \mu \mathrm{m}$ particles appearing several hours after rain events that we suggest are fungal spores actively emitted when ambient conditions are most advantageous for spread and germination. The pronounced patterns of fluorescent bioparticles observed here suggest that parameterizations of both daily and seasonal cycles will be important to accurately reflect bioparticle emissions in future studies of atmospheric bioaerosols and their potential effects on clouds and precipitation.

\section{Introduction}

Biogenic gases and particles are released into the atmosphere from every region and ecosystem of the planet and contribute significantly to many Earth, atmospheric, and human systems. Small particles of biological origin (e.g. pollen grains, spores of fungi and plants, bacteria, and cellular debris) emitted directly into the atmosphere, called primary biological aerosol particles (PBAP), can range in size from approximately 0.1 to $100 \mu \mathrm{m}$ and may be suspended for minutes to days (Womack et al., 2010; Després et al., 2012). While global estimates are uncertain, reports suggest that classes of PBAP exist in typical ambient concentrations of $\sim 10^{4} \mathrm{~m}^{-3}$ and often represent tens of percent of coarse particle number (Després et al., 2012 and references therein). PBAP not only play important roles in local and regional environments, but have also been observed after atmospheric transport of thousands of kilometers over land and oceans (Griffin et al., 2007; 
Polymenakou et al., 2008; Burrows et al., 2009a, b; Hallar et al., 2011), and can sometimes utilize the atmosphere as a suspended habitat for multiple generations (Womack et al., 2010). Bioparticles may also influence climate forcing as airborne ice nuclei (e.g. Morris et al., 2004; Möhler et al., 2007; DeMott et al., 2010), especially in pristine regions which lack significant anthropogenic influence (Prenni et al., 2009; Pöschl et al., 2010). Bacteria known to be high-temperature ice nucleators are ubiquitously observed in snow, rain, and fog water (Christner et al., 2008; Morris et al., 2008), and have also been observed in situ in clouds well above ground level (Pratt et al., 2009; DeLeon-Rodriguez et al., 2013). Thus, because the role of clouds in the global energy balance is so uncertain (IPCC, 2007), a better understanding of the concentrations and properties of PBAP may help constrain aspects of climate uncertainty (Hoose et al., 2010; Sesartic et al., 2012). Ice-active bioparticles have been observed to increase dramatically during rainfall (Huffman et al., 2013; Prenni et al., 2013; Tobo et al., 2013) and may influence precipitation down-wind of particle sources, such as plants that host ice-active bacteria or spores. PBAP, as ice nucleators, could thus influence precipitation patterns through humanor nature-induced landscape changes (Morris et al., 2013), though it is uncertain what fraction of ice-active bioparticles observed at ground level may be lofted to form clouds. Biological particles can also be inhaled into the lungs or deposited in the eyes or nasal passages, causing respiratory disease, allergies, and other health effects (e.g., Franze et al., 2005; Pöschl, 2005; Polymenakou et al., 2008; Després et al., 2012).

Despite the many systems that airborne bioparticles influence, detailed information about ambient PBAP patterns are missing, due largely to the fact that methods to detect and characterize them have been time consuming, costly, and prone to experimental bias. In particular, available techniques have traditionally been unable to detect PBAP with high time resolution or in narrow size fractions, and so timeresolved details of PBAP size, concentration, and source are poorly understood. Recent improvements in real-time measurement techniques have provided opportunities to monitor airborne bioparticles continuously at considerably higher frequency and lower cost. Field-portable techniques involving laser/light-induced fluorescence (LIF) have been particularly effective at rapidly providing information about PBAP in real time (e.g. Hairston et al., 1997; Kaye et al., 2005; Sivaprakasam et al., 2009; Pan et al., 2011; Robinson et al.; 2013). Two commercially available LIF biosensors have been applied to ambient bioparticle monitoring and have helped to reveal fine detail about atmospheric PBAP patterns not previously observed (Gabey et al., 2010; Huffman et al., 2010; Toprak and Schnaiter, 2013). The ultraviolet aerodynamic particle sizer (UV-APS; TSI, Shoreview, MN, USA) and the wideband integrated bioaerosol sensor (WIBS; Droplet Measurement Technologies, Boulder, CO, USA) both characterize biological particles in real time based on the intensity of fluorescence emission from individual particles after pulsed excitation at wavelengths characteristic for biofluorophores (Hill et al., 2009; O'Connor et al., 2011; Pöhlker et al., 2012, 2013). The UV-APS utilizes a single wavelength of excitation at $355 \mathrm{~nm}$ to induce fluorescence from molecules in the interrogated particle, including products of cellular metabolism (e.g. coenzymes $\mathrm{NAD}(\mathrm{P}) \mathrm{H}$ and riboflavin) among other biofluorophores (Eng et al., 1989; Pöhlker et al., 2012). Like all bioparticle detection techniques, real-time LIF instruments are not selective for all types of PBAP and each combination of excitation and emission bands can selectively detect different fluorophores and organisms with varying efficiency (Pöhlker et al., 2012, 2013). Further, some non-biological particle types have been shown to fluoresce in some cases (e.g. Bones et al., 2010; Huffman et al., 2010; Gabey et al., 2013; Lee et al., 2013). LIF instrument-specific biases can complicate classification of particles as biological and cross-comparison between detection strategies. Despite the uncertainty, fluorescent biological particles (FBAP) detected by the UV-APS or WIBS, though not rigorously the same quantity due to differing fluorescence bands, have been considered to be a lower-limit proxy for PBAP (Huffman et al., 2010). This assumption was shown to be appropriate for remote Amazonian air when comparing UV-APS results with those from optical and electron microscopy samples collected simultaneously (Pöschl et al., 2010; Huffman et al., 2012), though additional studies of this type will be necessary to test how the assumption may break down when sampling complex aerosol mixtures.

Studies of seasonal bioaerosol variability have been performed and reviewed previously (e.g. Jones and Harrison, 2004). Only recently have long-term studies involving realtime LIF techniques, and thus providing high time and size resolution to FBAP detection, been attempted (Toprak and Schnaiter, 2013). Seasonal PBAP studies are important, because environmental factors that determine PBAP emission follow clear seasonal cycles specific to ecosystem, and thus it is expected that airborne bioparticle patterns also follow seasonal cycles dictated by microorganism species. Without detailed, long-term measurements, the ability to correctly model atmospheric effects of PBAP is significantly diminished. Here we compare continuous UV-APS measurements from two rural, forested sites: 18 months (2009-2011) in Hyytiälä, Finland and 10 months (2011-2012) near Woodland Park, Colorado, USA. To our knowledge this study provides the first report of a full seasonal cycle of UV-APS measurement data in the scientific literature and is the first to compare annual cycles of fluorescence bioparticle measurements from two geographic locations. 


\section{Methods}

\subsection{UV-APS operation}

The UV-APS draws in ambient aerosol and utilizes the time of particle flight between two red lasers $(633 \mathrm{~nm})$ to measure particle aerodynamic diameter $\left(D_{\mathrm{a}}\right)$ in 52 channels between 0.5 and $20 \mu \mathrm{m}$. A third laser $(355 \mathrm{~nm})$ is pulsed at each individual particle, and the intensity of the resultant fluorescence in the wavelength range of $420-575 \mathrm{~nm}$ (single channel; not wavelength-dispersed) is recorded (Hairston et al., 1997; Brosseau et al., 2000). Though particles as small as $\sim 0.3 \mu \mathrm{m}$ can be detected, the particle collection efficiency drops below unity at approximately $0.8 \mu \mathrm{m}\left(D_{50} \sim 0.5 \mu \mathrm{m}\right.$, Huffman et al., 2010, 2012). Thus, particle distributions that appear to peak at $\sim 0.8 \mu \mathrm{m}$ are likely to be the tail of a larger mode (i.e. accumulation mode) peaking at smaller sizes. In addition, the influence of fluorescence from non-biological particles has been suggested to occasionally increase at small particle sizes (Huffman et al., 2010). For these reasons we chose $1.0 \mu \mathrm{m}$ as the lower limit for integrated coarse particle numbers $\left(N_{\mathrm{c}}\right)$. It has also been shown that ambient UV-APS measurements can inadvertently conflate biological material into the non-fluorescent category based on the fact that many microorganisms fluoresce only weakly and thus escape realtime LIF detection (Huffman et al., 2012). We utilize subscripts $\mathrm{T}$ and $\mathrm{F}$ to refer to total and fluorescent particles in the super-micron size range, respectively (e.g. $N_{\mathrm{T}, \mathrm{c}}$ and $N_{\mathrm{F}, \mathrm{c}}$ ). The upper limit on detectable particle size is practically defined by inlet engineering, but is limited to $\sim 20 \mu \mathrm{m}$ by the UV-APS. Samples of ambient air were drawn through a total suspended particle (TSP) inlet head in each location and into the instrument at $5 \mathrm{~L} \mathrm{~min}^{-1}$, where flow was split into $1 \mathrm{~L} \mathrm{~min}^{-1}$ of sample flow and $4 \mathrm{~L} \mathrm{~min}^{-1}$ of filtered sheath flow. The sampling frequency was every $5 \mathrm{~min}$, with $285 \mathrm{~s}$ used for sample integration and $\sim 15 \mathrm{~s}$ used for data transfer from the UV-APS board to the dedicated computer (Huffman et al., 2010).

\subsection{Finland sampling}

The UV-APS was operated from inside the aerosol cottage at the SMEAR-II (Station for Measuring EcosystemAtmosphere Relations-II, $181 \mathrm{~m}$ elevation, lat. $61.85^{\circ} \mathrm{N}$; lon. $24.17^{\circ} \mathrm{E}$ ) (Hari and Kulmala, 2005) in Hyytiälä, Finland from 27 August 2009 to 17 April 2011 (598 days, 164989 total $5 \mathrm{~min}$ samples). The sampling site is in a $51 \mathrm{yr}$ old Scots pine forest that has been used extensively for atmospheric monitoring and has been described in detail elsewhere ${ }^{1}$. The average tree canopy height at the sampling site is $16.8 \mathrm{~m}$, with leaf area index averaging between 2.5 and 3 . For collection of meteorological data, the inlet was placed at $16.8 \mathrm{~m}$, however, the tops of the trees immediately surrounding the tower were below that of the inlet. The TSP

\footnotetext{
${ }^{1}$ http://www.atm.helsinki.fi/SMEAR
}

inlet utilized for this study was placed approximately $4 \mathrm{~m}$ above ground level and $1 \mathrm{~m}$ above the cottage roof. The total flow through this inlet $\left(10 \mathrm{~L} \mathrm{~min}^{-1}\right)$ was split between the UV-APS and a standard APS after being drawn vertically down through stainless steel tubing ( 0.75 in. outer diam.). The APS flow passed directly, and the UV-APS flow split at a $\sim 45^{\circ}$ angle via a y-splitter and was brought to the instrument through $\sim 0.7 \mathrm{~m}$ conductive rubber tubing ( $0.75 \mathrm{in}$. inner diam.; Simolex Rubber Corp., Plymouth, MI). New data files were initiated approximately every 7 days to keep the number of recorded $5 \mathrm{~min}$ samples per file manageable. The cottage was temperature-regulated during winter, and the inlet tube was mildly heated during warm months with a wrapped heating tape to prevent water vapor condensation upon entering the cooler lab.

\subsection{Colorado sampling}

The Colorado experiment took place within the Manitou Experimental Forest $\left(2370 \mathrm{~m}\right.$ elevation, lat. $39.10^{\circ} \mathrm{N}$; lon. $105.09^{\circ} \mathrm{W}$ ), located approximately $48 \mathrm{~km}$ northwest of Colorado Springs, Colorado in a rural, semi-arid region of the central Rocky Mountains (2290 m a.s.l.). The closest town (Woodland Park) is located $15 \mathrm{~km}$ to the south. The vegetation surrounding the site is mixed pine forest, representative of large areas of the North American West (Ortega et al., 2013) ${ }^{2}$. Ponderosa pines sparsely cover the study area, averaging $10-20 \mathrm{~m}$ in height, with leaf area index variable, but averaging $\sim 1.9$ (DiGangi et al 2011). Sampling was initiated as a part of the BEACHON-RoMBAS (Bio-hydroatmosphere interactions of Energy, Aerosols, Carbon, $\mathrm{H}_{2} \mathrm{O}$, Organics and Nitrogen - Rocky Mountain Biogenic Aerosol Study) ${ }^{3}$ intensive field campaign July-August 2011 (Ortega et al., 2013), and continued for almost a calendar year (20 July 2011-31 May 2012; 861025 min sample points). The UV-APS was located in a climate-controlled (heating and cooling) trailer approximately $300 \mathrm{~m}$ from a local highway. A TSP inlet head was mounted approximately $2 \mathrm{~m}$ above the trailer roof, which was approximately $4 \mathrm{~m}$ above ground level. Stainless steel tubing (outer diam. 0.75 in) ran vertically to an opening at the top of the trailer side wall. Approximately $1.5 \mathrm{~m}$ of electrically conductive rubber tubing ( $0.75 \mathrm{in}$. inner diam.; Simolex) was connected to the vertical inlet tube and bent at a $\sim 30^{\circ}$ angle to pass into the trailer, then connecting to the vertical UV-APS instrument inlet piece. Data files were typically initiated every $1-$ 3 days during the intensive BEACHON-RoMBAS campaign (20 July-23 August 2011) and every 7-40 days for the rest of the sampling period.

\footnotetext{
${ }^{2}$ http://web3.acd.ucar.edu/beachon/

${ }^{3} \mathrm{http}: / /$ cires.colorado.edu/jimenez-group/wiki/index.php/ BEACHON-RoMBAS
} 


\subsection{Season definitions and ancillary instrumentation}

For the long-term comparisons between the two sites, we averaged time periods into seasons, as defined meteorologically: Spring (1 March-31 May), Summer (1 June-31 August), Fall (1 September-30 November), and Winter (1 December-29 February) (Trenberth, 1983).

Meteorological instruments measuring air temperature, relative humidity, barometric pressure, rain rate, wind speed, and wind direction are operated continuously at both sites and recorded data were used for comparison. These instruments were located at $16.8 \mathrm{~m}$ above ground at the Finland site and $8 \mathrm{~m}$ above ground at the Colorado site. Reported accuracy for meteorological measurements made at the Colorado site are as follows: temperature $\pm 0.3{ }^{\circ} \mathrm{C} ; \mathrm{RH} \pm 3 \%$ for all $\mathrm{RH}$ values $<90 \%$ and $\pm 5 \%$ for all $\mathrm{RH}$ values $>90 \%$; precipitation $\pm 0.25 \mathrm{~mm}$. Reported accuracy for RH at the Finland site is within $\pm 3 \%$.

\section{Results and discussion}

\subsection{General trends}

\subsubsection{Particle concentration}

The UV-APS was operated at each sampling location for a minimum of 10 months to evaluate the respective seasonal cycles of total and fluorescent biological particles. Though in very different sampling climates and environments, the seasonal trends at each location exhibit broadly similar patterns of higher FBAP concentrations in summer than in winter (Figs. 1-2, Table 1). FBAP at each site was highest May to October, and lowest December to February, however, the relative increase between winter and summer was greater at the Finland site (factor of 12) than at the Colorado site (factor of 5). The Colorado measurements were performed for just less than one full seasonal cycle, whereas measurements were performed in Finland continuously for 18 months, allowing for comparison of late summer, fall, and winter seasons for two consecutive years. From this comparison (Fig. 1) the FBAP concentration data show fluctuations at weekly timescales or less, but are consistent between years at the seasonal level.

For example, the magnitude of winter concentrations and the time period of decrease from elevated summer values (approx. mid-September) are each similar during the years of the Finland study. The low concentration of FBAP in winter is expected, due to the cold temperatures and snow cover in both locations, and is also similar to the general trend observed over a year-long study in SW Germany by Toprak and Schnaiter (2013). Environmental factors were expected to lower the concentration of airborne biological particles due to the reduced biological activity during winter and the reduced ability of microorganisms to become lofted to the air because of the snow coverage barrier. During the win- ter of 2011-2012, the Colorado site received $\sim 120 \mathrm{~cm}$ of snow (D. Gochis, personal communication, 2013). However, during this period there were often long periods of dry, exposed ground (Ortega et al., 2013), whereas the ground at the Finland site was continuously snow-covered from early November to mid-April (Fig. 1). This may partially explain the lower absolute concentrations in winter at the Finland site compared to the Colorado site, although the mean temperature is also lower and the latitude is higher at the Finland site. The FBAP dampening effect of low temperatures and snow cover in Finland is further suggested by a short period of relative increase in FBAP concentration during the late fall season 2009 (Fig. 1, green trace). Well after the FBAP concentration began to drop for the season in mid-September, and after the first few days of snow cover (9-16 November), approximately two weeks of warmer temperatures melted the snow and resulted in a marked increase in FBAP concentration. This short trend continued until a sharp decrease in temperature (1 December) caused a drop in FBAP by approximately 2 orders of magnitude. The total coarse aerosol concentration (Fig. S1) was unaffected by the steep temperature drop, however, and so the FBAP number fraction (Fig. S2) dropped precipitously and remained low until the beginning of spring 2010.

Seasonal bioaerosol measurements were previously performed at the Hyytiälä, Finland site, using a Burkard spore trap for sampling and optical microscopy for analysis, for part of two consecutive years (2003-2004) and show airborne fungal spore concentrations as having a very similar seasonal trend as FBAP reported here (Manninen et al., 2013), consistent with observations reported here. Several other studies reporting measurements from rural Scandinavia and northern Asia have also reported similar seasonal trends, such as Kaarakainen et al. (2008) who showed fungi and bacteria concentrations from polymerase chain reaction (PCR) measurements were the highest in summer, also elevated in fall, and lowest in winter in central Finland. Mäkinen and Ollikainen (1973) discuss fungal spore concentrations peaking in summer and fall in an urban area of Finland, citing a number of previous studies showing various observations of seasonal trends for individual spore species. Matthias-Maser et al. (2000) show PBAP, using electron microscopy, peaking in summer at a remote Siberian sampling location. Thus, a number of studies have established the general trend of bioaerosol concentrations the highest during warm months at high latitudes. However, until recently the availability to investigate such trends at fine temporal resolution has not been available.

While FBAP concentrations show a seasonal trend peaking during warm months at both locations, trends for total coarse particles are distinctly different from those of FBAP. At the Finland site, no clear seasonal trend in total particle concentration was observable (Fig. S1a); mean concentration remained relatively constant across seasons. The total coarse particle number concentration in Colorado was the highest during spring and summer (Fig. S1b), in contrast 


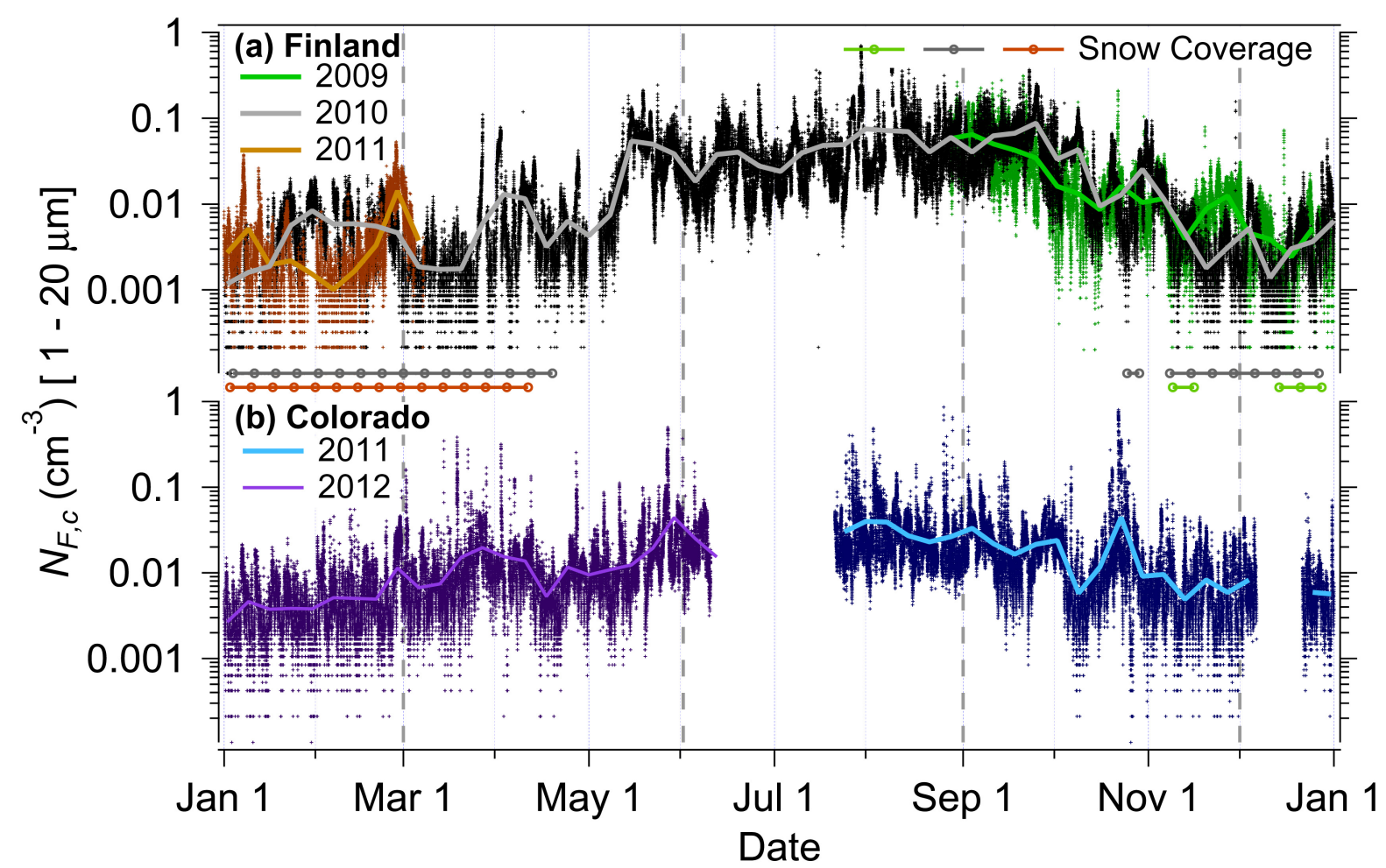

Fig. 1. Overview of FBAP concentration and key meteorological data at each site. Small dots represent individual 5 min data points from UV-APS. Colored traces cutting through UV-APS data show 7-day mean values of FBAP concentration. Axis ranges matched in upper and bottom panels. Open circle markers represent periods of ground snow cover at Finland site (not available at Colorado site) and are shown for each recorded observations (approximately every week through winter season). Dashed grey vertical lines show seasonal boundaries used for averaging (as discussed in Sect. 2.4).
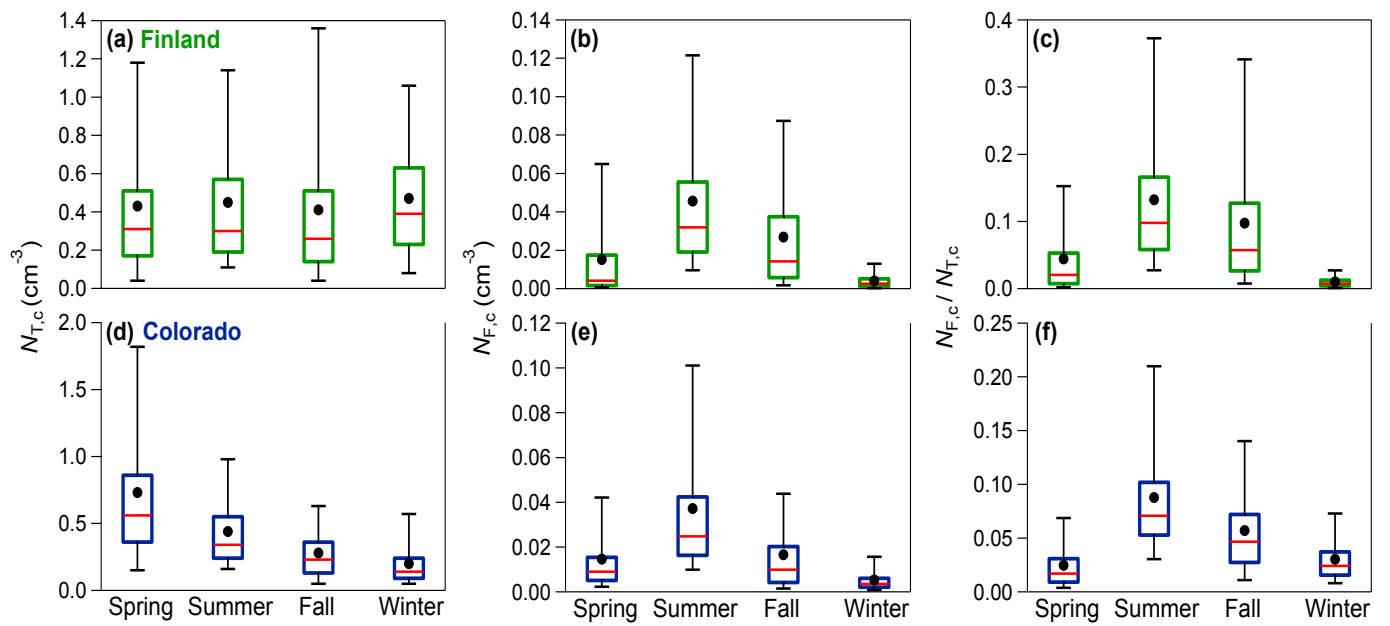

Fig. 2. Seasonal concentrations of coarse-mode total and fluorescent bioparticles. Finland site shown in upper panels as green boxes, and Colorado site shown in lower panels as blue boxes. Whisker plots represent mean and median values (black dots, red lines, respectively), 25th and 75th percentiles (boxes), 5th and 95th percentiles (vertical lines) (a) Concentrations of total particles, $N_{\mathrm{T}, \mathrm{c}}$. (b) Concentration of fluorescent bioparticles, $N_{\mathrm{F}, \mathrm{c}}$ (c) Ratio of fluorescent to total particles, $N_{\mathrm{F}, \mathrm{c}} / N_{\mathrm{T}, \mathrm{c}}$. 
Table 1. Seasonal comparison of coarse-mode total aerosol particle $\left(N_{\mathrm{T}, \mathrm{c}}\right)$, fluorescent biological aerosol particle $\left(N_{\mathrm{F}, \mathrm{c}}\right)$ and bioparticle ratio $\left(N_{\mathrm{F}, \mathrm{c}} / N_{\mathrm{T}, \mathrm{c}}\right)$ trends at Finland and Colorado sites. Particle concentrations shown as arithmetic mean values averaged over entire season. Variability in each case listed as \pm standard deviation. Particle modes discussed represent most consistently observed peaks in particle size distribution, not necessarily corresponding to peaks in size distribution averages. Mode width listed as: $(+)$ broad, $(++)$ very broad, $(-)$ narrow. Qualitative correlation of $N_{\mathrm{F}, \mathrm{c}}$ with rainfall listed as: strongly positive, moderately positive, slightly positive, or none. Rain was not observed during winter season at either sampling location due to cold temperatures.

\begin{tabular}{|c|c|c|c|c|}
\hline \multicolumn{5}{|c|}{ Hyytiälä, Finland } \\
\hline & Spring & Summer & Fall & Winter \\
\hline$N_{\mathrm{T}, \mathrm{c}}\left(\mathrm{cm}^{-3}\right)$ & $0.43 \pm 0.53$ & $0.45 \pm 0.39$ & $0.41 \pm 0.42$ & $0.47 \pm 0.34$ \\
\hline$N_{\mathrm{F}, \mathrm{c}}\left(\mathrm{cm}^{-3}\right)$ & $0.015 \pm 0.024$ & $0.046 \pm 0.048$ & $0.027 \pm 0.032$ & $0.004 \pm 0.0046$ \\
\hline$N_{\mathrm{F}, \mathrm{c}} / N_{\mathrm{T}, \mathrm{c}}$ & 0.044 & 0.13 & 0.098 & 0.011 \\
\hline \multirow{3}{*}{ Particle Modes $(\mu \mathrm{m})$} & & & $<1.0(-)$ & \\
\hline & $1.5(-)$ & $1.5(-)$ & $1.5(-)$ & $1.5(+)$ \\
\hline & $3.0(+)$ & $3.0(-)$ & $3.0(-)$ & $2.5(+)$ \\
\hline Temperature $\left({ }^{\circ} \mathrm{C}\right)$ & $2.3 \pm 7.4$ & $16.3 \pm 5.3$ & $3.6 \pm 6.7$ & $-10.6 \pm 6.4$ \\
\hline Relative Humidity (\%) & $72 \pm 20$ & $61 \pm 18$ & $83 \pm 12$ & $97 \pm 4$ \\
\hline $\begin{array}{l}N_{\mathrm{F}, \mathrm{c}} \text { vs. Rain } \\
\text { (Correlation) }\end{array}$ & $\begin{array}{r}\text { moderately } \\
\text { positive }\end{array}$ & $\begin{array}{r}\text { moderately } \\
\text { positive }\end{array}$ & $\begin{array}{l}\text { slightly } \\
\text { positive }\end{array}$ & $\begin{array}{r}\text { none } \\
\text { observed }\end{array}$ \\
\hline Diurnal $N_{\mathrm{F}, \mathrm{c}}$ Peak (Hour of Day) & 02:00 & 23:00 & 20:00 & 23:00 \\
\hline \multicolumn{5}{|c|}{ Manitou Experimental Forest Observatory, Colorado } \\
\hline & Spring & Summer & Fall & Winter \\
\hline$N_{\mathrm{T}, \mathrm{c}}\left(\mathrm{cm}^{-3}\right)$ & $0.73 \pm 0.72$ & $0.44 \pm 0.29$ & $0.28 \pm 0.23$ & $0.20 \pm 0.20$ \\
\hline$N_{\mathrm{F}, \mathrm{c}}\left(\mathrm{cm}^{-3}\right)$ & $0.015 \pm 0.024$ & $0.030 \pm 0.030$ & $0.017 \pm 0.031$ & $0.0053 \pm 0.0063$ \\
\hline$N_{\mathrm{F}, \mathrm{c}} / N_{\mathrm{T}, \mathrm{c}}$ & 0.025 & 0.088 & 0.057 & 0.030 \\
\hline \multirow{2}{*}{ Particle Modes $(\mu \mathrm{m})$} & $2.0(+)$ & $2.0(++)$ & $1.5(+)$ & $1.5(+)$ \\
\hline & $5.0(+)$ & $4.5(++)$ & $5.0(+)$ & $5.0(+)$ \\
\hline Temperature $\left({ }^{\circ} \mathrm{C}\right)$ & $6.8 \pm 8.5$ & $17.7 \pm 7.2$ & $5.6 \pm 8.6$ & $-3.8 \pm 7.5$ \\
\hline Relative Humidity (\%) & $48 \pm 30$ & $52 \pm 29$ & $56 \pm 28$ & $57 \pm 26$ \\
\hline $\begin{array}{l}N_{\mathrm{F}, \mathrm{c}} \text { vs. Rain } \\
\text { (Correlation) }\end{array}$ & $\begin{array}{r}\text { moderately } \\
\text { positive }\end{array}$ & $\begin{array}{l}\text { strongly } \\
\text { positive }\end{array}$ & $\begin{array}{r}\text { moderately } \\
\text { positive }\end{array}$ & $\begin{array}{r}\text { none } \\
\text { observed }\end{array}$ \\
\hline Diurnal $N_{\mathrm{F}, \mathrm{c}}$ Peak (Hour of Day) & 23:00 & $22: 00$ & 03:00 & $22: 00$ \\
\hline
\end{tabular}

to the FBAP trend, but the magnitude of increase from the lowest to the highest seasons was only a factor of $\sim 2$. Total particle number also exhibited significantly reduced daily and weekly variability as compared with FBAP (see vertical scatter in Figs. 1 and S1). The seasonal behavior of the ratio of FBAP to total coarse particles (Fig. S2) is similar to that of FBAP, showing that changes in the seasonal coarse aerosol composition are dominated by changes in FBAP and not by total particles. For example, it has been speculated that atmospheric dilution caused by the increasing boundary layer height might cause the often observed decrease in FBAP concentration during the day. Seasonal averages of particle concentration do not clearly support this suggestion, however, because concentrations of coarse particle in winter at both sites are similar to, or well below, summertime averages when the boundary layer height is expected to be much higher. Physical effects of atmospheric dilution would also be expected to treat biological and non-biological particles similarly, suggesting that the observed wintertime decreases in FBAP are indeed less related to atmospheric dilution than to changes in biological emission patterns. Further, the seasonally stable total coarse aerosol concentration at the Finland site, despite months of continuous snow coverage, suggests that the atmospheric source of total particles is not dominated by wind-blown re-suspension of soil or leaf litter and, by extension, that observed FBAP at this location is not primarily attached to lofted mineral dust particles. These observations thus suggest that boundary layer effects may contribute more weakly to FBAP trends than do biological factors, as also suggested by Huffman et al. (2012). 


\subsubsection{Size of biological particles}

Size distributions of FBAP number concentrations reflect typical peaks between 1-7 $\mu \mathrm{m}$ in all cases reported here. However, while particle concentration trends were consistent between the two measurements sites, trends in particle size were less so, indicating differences in the bioaerosol sources between the sites. Season-average FBAP size distributions from the Finland site (Fig. 3) show relatively narrow peaks at approximately $2.5 \mu \mathrm{m}$ and a shoulder at approximately $1.2 \mu \mathrm{m}$ for each individual season average for spring, summer, and fall. Though the peaks of the seasonally averaged size distributions are relatively narrow, they are comprised of and broadened by peaks of individual bioaerosol types at different sizes. This idea is highlighted by Fig. 4c, which shows an example of size distributions averaged over a relatively short time period $(\sim 6 \mathrm{~h})$, where discreet particle modes are resolved enough to see their influence to the average distribution.

Through the seasons sampled at the Finland site, particle modes were observed to vary significantly in particle size and concentration, but three modes were consistently observed, at $\sim 1.5, \sim 3$, and $\sim 5 \mu \mathrm{m}$, in addition to particles occasionally present at $<1 \mu \mathrm{m}$. The mode at $\sim 3 \mu \mathrm{m}$, however, was the most common individual mode, and was often observed to have extremely narrow distribution width. Further, the fraction of particles represented by each of these three individual modes observed during spring through fall was not obviously correlated with meteorological variables and is thought to have been influenced heavily by local biological activity. The FBAP modes observed here are consistent with results from a recent laboratory study, revealing that the average aerodynamic spore size of 66 fungal species collected from around Hyytiälä to be between 1.5-5.1 $\mu \mathrm{m}$ (Hussein et al., 2013). Figure 5 shows an example of a period with the narrow FBAP mode that is stable both in size and concentration for several days at a time during the fall. The peak was commonly observed to be large enough to overwhelm the size distribution of total particles (Fig. 5a), a rare scenario among ambient UV-APS observations to date. The FBAP peak clearly influences the total particle distribution at that size, but $N_{\mathrm{F}, \mathrm{c}}$ only represents $51 \%$ of $N_{\mathrm{T}, \mathrm{c}}$ at the peak of the distribution (Fig. 5b). Each particle mode has a distribution of particle size and fluorescence intensity, and the instrument detector sensitivity defines whether an interrogated particle will be counted as fluorescent. Huffman et al. (2012) showed that the UV-APS can sometimes undercount fluorescence from particles of a single mode. Low fluorescence sensitivity parameters are used to purposefully reduce possible interference from weakly fluorescent, non-biological particles. The evidence here supports the previous observation of a single mode containing a distribution of fluorescence intensity. Thus, the remaining $49 \%$ of particles in the mode observed here (Fig. 5) exhibit fluorescent emissions below the FBAP threshold, but are likely to be biological particles

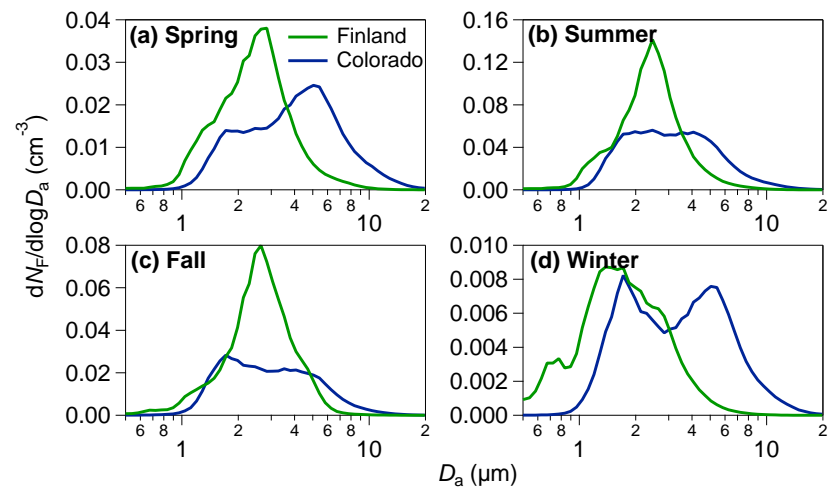

Fig. 3. Mean FBAP number distributions, $\mathrm{d} N_{\mathrm{F}} / \mathrm{d} \log D_{a}$ during (a) Spring (b) Summer (c) Fall (d) Winter seasons at Finland (green) and Colorado (blue) sites.
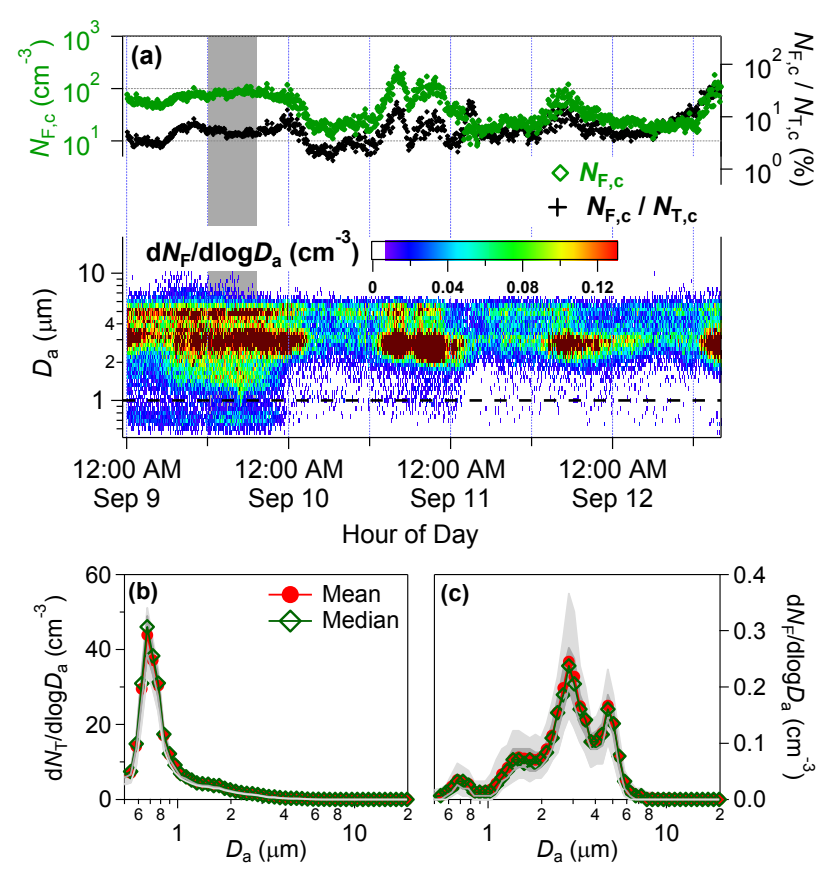

Fig. 4. Representative particle modes present at Finland site. (a) Image plot with gray bar highlighting period of average (14:56-21:06, 9 September 2009). Size distributions of (b) $N_{\mathrm{T}}$ and (c) $N_{\mathrm{F}}$. Mean and mean traces shown as colored traces, with gray region showing inner quartile.

whose physiological or metabolic state has changed, leading to a change in fluorophore content (Wu and Warren, 1984a, b; Roshchina, 2003; Tack et al., 2013).

Despite the relative consistency during fall through spring, the winter average size distribution at the Finland site (Fig. 3d) is qualitatively different than the other three seasons, with the highest observed peak at $1.2 \mu \mathrm{m}$ and with the $2.5 \mu \mathrm{m}$ peak as a large shoulder. Additionally, both the fall and winter averages show a small peak at $0.8 \mu \mathrm{m}$. However, this is a false "peak" caused by instrument collection 
efficiency that drops below unity at approximately $0.8 \mu \mathrm{m}$. It is therefore impossible to know the shape of the distribution below this particle size from UV-APS data, but it is likely that these particles are the tail of a larger, accumulation mode peaking well below $1 \mu \mathrm{m}$ (Dal Maso et al., 2005). With rare exception (e.g. Fig. 4c), these small particles were generally only observed in fall and winter. For example, when the temperatures are low, the atmospheric boundary layer is also usually lower, increasing the particle concentration within a smaller volume. Thus, these particles may be related to wood-burning emissions during cold days when the boundary layer is shallow and may be small pieces of ash, or PAHcontaining particles that could fluoresce strongly (Aizawa and Kosaka, 2008).

In contrast to the Finland site, the trends in the average FBAP size distribution from the Colorado site show two clearly separated modes at approximately 1.5 and $5.0 \mu \mathrm{m}$, with the exception being summer when additional modes resulting from rain influence were commonly observed (see Sect. 3.2.3), leading to a broad single peak. Also in contrast to the Finland site, the number of individual FBAP modes observed in Colorado at any given time was usually fewer, and season averages more closely approximate the qualitatively stable size distributions on any given day. The submicron FBAP mode was not observed at the Colorado site, possibly because it is more remote than the Hyytiälä station with respect to residential areas and thus has less influence from nearby wood burning.

\subsubsection{Diurnal patterns}

One of the benefits of high-time resolution LIF bioaerosol techniques is the ability to easily analyze diurnal (daily or $24 \mathrm{~h}$ ) averages of size distributions and total concentrations and to monitor how these patterns change over time. Consistent to what has been reported previously (Huffman et al., 2010; Gabey et al., 2011; Toprak and Schnaiter, 2013), $N_{\mathrm{F}, \mathrm{c}}$ and $N_{\mathrm{F}, \mathrm{c}} / N_{\mathrm{T}, \mathrm{c}}$ at both the Finland and Colorado sites peak during every season in the evening or early morning hours when relative humidity $(\mathrm{RH})$ is the highest and temperature is the lowest (see also Sect. 3.2). Seasonally averaged diurnal plots for the Finland site highlight the extremely narrow mode at $\sim 3 \mu \mathrm{m}$ (Fig. S3). Similar particle size distribution plots for the Colorado site (Fig. S4), however, show size distributions peaking at 2,3 , and $5 \mu \mathrm{m}$ at different times of the night for different seasons. These patterns are discussed in more detail in the Supplement.

\subsection{Meteorological effects on fluorescent bioparticles}

\subsubsection{Temperature effects}

Over the course of the year and as a function of whole season averages there is a positive correlation between temperature and $N_{\mathrm{F}, \mathrm{c}}$ (Fig. S5). Increasing the ambient temperature
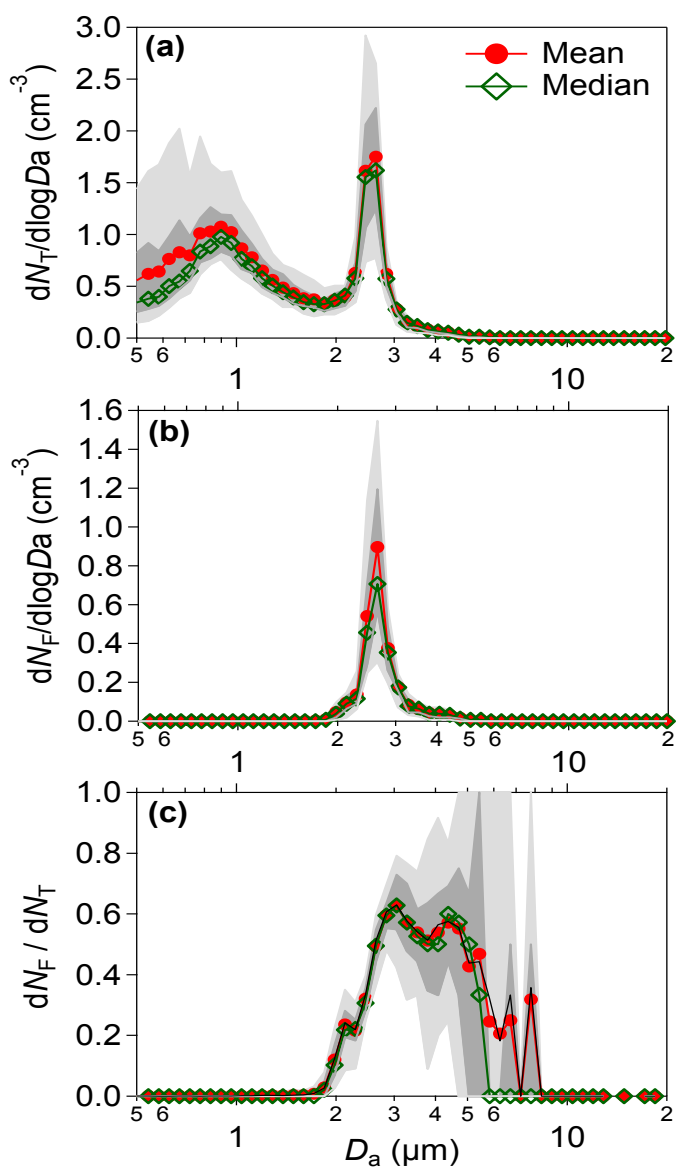

Fig. 5. $\mathrm{d} N_{\mathrm{T}} / \mathrm{d} \log D_{\mathrm{a}}$, and $\mathrm{d} N_{\mathrm{F}} / \mathrm{d} \log D_{\mathrm{a}}$ size distributions from Finland site showing narrow FBAP peak at $2.64 \mu \mathrm{m}$. Average of samples from 8 October 2009 18:53-21:51, (35 total samples). Mean and median lines shown as red and green traces, respectively. Dark gray zone shows $25-75$ th percentiles, and light gray zone shows 5th-95th percentiles.

appears to increase the relative number of FBAP. These seasonal trends are misleading, however, because the trend as viewed on a daily basis (Figs. S3 and S4) shows that $N_{\mathrm{F}, \mathrm{c}}$ decreases with increasing temperature during the day. This suggests that biological processes that determine the release of bioaerosols are strongly a function of season and may require a certain minimum temperature to function. Spring recovery in connection with the increased photosynthetic activity of the biosphere has also been linked to nanoparticle formation (Dal Maso et al. 2009). Once the biological activity has been initiated, however, higher temperatures and lower RH during the day actually attenuate bioaerosol release. At the Finland site, $N_{\mathrm{F}, \mathrm{c}}$ appears relatively constant at $\sim 0 \mathrm{~cm}^{-3}$ until the temperature in any season exceeds $\sim 0{ }^{\circ} \mathrm{C}$, likely due to snow melting, at which point $N_{\mathrm{F}, \mathrm{c}}$ increases with temperature (Fig. S5a). At the Colorado site, the minimum temperature was not as consistent or definitive, but exceeding a threshold of approximately $-5^{\circ} \mathrm{C}$ appears necessary for $N_{\mathrm{F}, \mathrm{c}}$ to 
increase (Fig. S5b). Ambient temperature has been shown to influence fungal spore release, but this process is strongly a function of fungal species. Airborne fungi are highly diverse and some species (e.g. Cladosporium) favor release during warm, dry periods, whereas other spores (e.g. many basidiospores and ascospores) favor release during cooler, wet periods (De Groot, 1968; Gilbert, 2005; Elbert et al., 2007; Fröhlich-Nowoisky et al., 2009, 2012; Huffman et al., 2013).

\subsubsection{Humidity effects}

Air temperature correlates strongly, but inversely, with RH by affecting the saturation water vapor pressure in air. So it is no surprise that $N_{\mathrm{F}, \mathrm{c}}$ shows an opposite daily trend with RH than with temperature (e.g. Gregory and Hirst, 1957; Gottwald et al., 1997; Burch and Levetin, 2002; Elbert et al., 2007; Santarpia et al., 2013). However, in contrast to temperature, $\mathrm{RH}$ shows the same general correlation with $N_{\mathrm{F}, \mathrm{c}}$ on both daily and seasonal levels (Figs. 6, S3 and S4). At the Finland site (Fig. 6a) RH levels in winter are generally higher due to lower temperatures, but $N_{\mathrm{F}, \mathrm{c}}$ is almost continuously near zero, thus showing little correlation. During spring and fall the average $N_{\mathrm{F}, \mathrm{c}}$ concentration is higher, but the relationship between $N_{\mathrm{F}, \mathrm{c}}$ and RH is inconsistent. During summer there is a clearly positive correlation between $N_{\mathrm{F}, \mathrm{c}}$ and $\mathrm{RH}$ from $\sim 30-82 \% \mathrm{RH}$, suggesting that many of the bioparticles detected could be ejected actively by RH-dependent mechanisms (Ingold, 1999; Pringle et al., 2005; Elbert et al., 2007). Above $\mathrm{RH} \sim 82 \%$ during summer, however, $N_{\mathrm{F}, \mathrm{c}}$ decreases substantially. A similar trend was observed using UV-APS data from a remote site in Amazonia (Huffman et al., 2012), but was unexplained. Measurements of temperature and RH allow estimation of dew point for each sample, though surface temperature and RH on or immediately above vegetative surfaces may be somewhat different from measurements at $8 \mathrm{~m}$ above the forest floor. $\mathrm{RH}$ of $\sim 82 \%$ corresponds, on average, to a temperature $\sim 2.7^{\circ} \mathrm{C}$ above the dew point of water (Fig. S6). Therefore, we hypothesize that at this RH dew is beginning to form on plant and terrestrial surfaces, thus applying a layer of water through which spores and other bioparticles are unable to escape. This, in turn, lowers the FBAP concentration. Jones and Harrison (2004) also summarized reported observations of reduced spore concentration after dew formation or rainfall, suggesting that rates of spore release were tied closely to changes in surface wetness. It is also possible that this hypothesis could partially explain why RH lags behind $N_{\mathrm{F}, \mathrm{c}}$ in the diurnal cycle (Sect. S1.1, Figs. S3 and S4). Many species of fungi utilize increased RH overnight to promote active spore release, but the formation of dew when RH peaks may inhibit the ability of spores to overcome local the micro-scale boundary layer. Thus $N_{\mathrm{F}, \mathrm{c}}$ would begin to decrease in the morning as dew begins to form and before $\mathrm{RH}$ decreases.

The trends observed at the Finland site are broadly similar for the Colorado site: (1) $N_{\mathrm{F}, \mathrm{c}}$ is very low during winter,
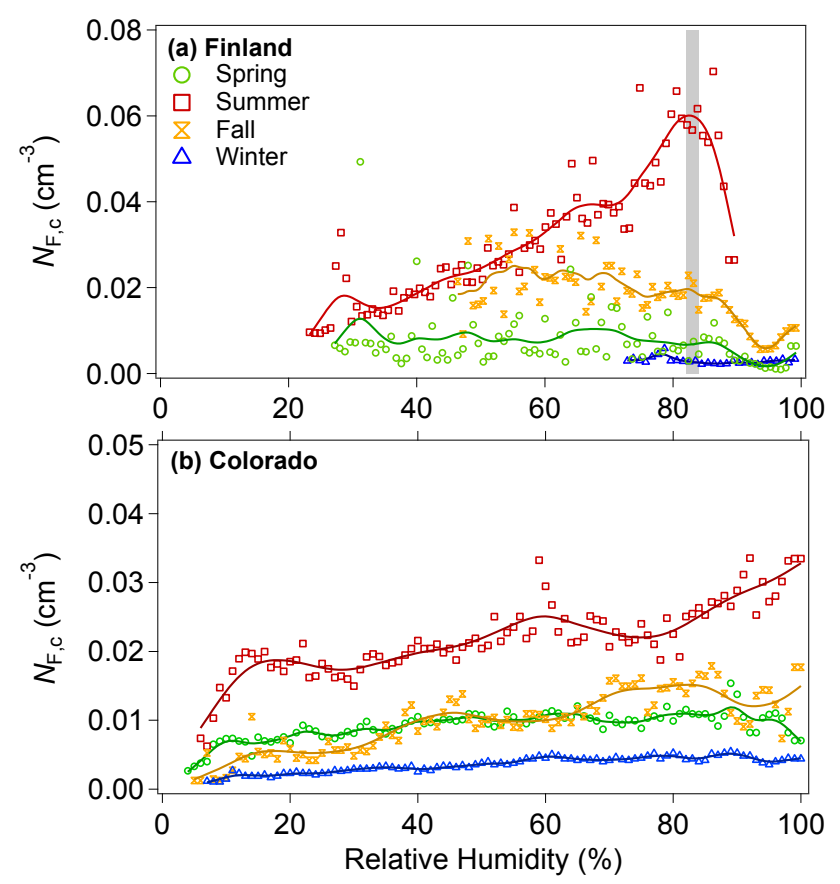

Fig. 6. Seasonal correlation of median bioparticle concentration $\left(N_{\mathrm{F}, \mathrm{c}}\right)$ with relative humidity $(\mathrm{RH})$ at (a) Finland and (b) Colorado sites. Data averaged into $100 \mathrm{RH}$ bins. Bins containing less than $0.02 \%$ of the total points were removed. Fit lines are spline curves to guide the eye. Gray bar shows approximate $\mathrm{RH}$ value where FBAP concentration decreases.

(2) during spring and fall $N_{\mathrm{F}, \mathrm{c}}$ is somewhat higher, but the relationship with RH is inconsistent, and (3) during summer the positive correlation between $N_{\mathrm{F}, \mathrm{c}}$ and $\mathrm{RH}$ is clear. The Colorado site shows a consistent, positive relationship between RH and FBAP concentration. The relationship of $N_{\mathrm{F}, \mathrm{c}}$ with RH could be important for modeling bioaerosol emission, and periods of strong correlation suggests that concentrations measured under these conditions were dominated by recent, local emission, rather than by long-range transport.

\subsubsection{Precipitation effects}

In addition to FBAP patterns associated with daily temperature and RH cycles, during some seasons we observed sudden, substantial increases in FBAP concentrations immediately upon arrival of rain. Such correlations scaled with rain intensity, with FBAP increases the strongest during heavy rain, but still observed during light drizzle. The relationship between bioparticles and rain has been reported previously (Faulwetter, 1917; Gregory and Hirst, 1957; Hirst and Stedman, 1963; Fitt et al., 1989; Constantinidou et al., 1990; Pinkerton et al., 1998; Allitt, 2000; Paul et al., 2004; Huffman et al., 2013; Prenni et al., 2013), and was especially apparent during the summer season at the Colorado site, when even weak or short rain events were observed to increase $N_{\mathrm{F}, \mathrm{c}}$ by a factor of 6-40 over the concentration 
present immediately before precipitation began. Rain also caused an increase in the total particle concentration, though by a smaller factor than $N_{\mathrm{T}, \mathrm{c}}$ (about an average of $1.3 \times$ ) than $N_{\mathrm{F}, \mathrm{c}}$. Huffman et al. (2013) discussed that increases in aerosol concentration did not correlate with changes in wind patterns before or during storm arrival, and submicron aerosol concentrations follow a different temporal pattern related to rain (Laakso et al., 2003). Cluster analysis of WIBS data (Crawford et al., 2013; Robinson et al., 2013) and microscopy images from samples collected during BEACHONRoMBAS in Colorado (Huffman et al., 2013) suggest the majority of the increase in total particles was caused by bioparticles, despite UV-APS categorization as non-fluorescent.

Aerosol concentrations during and after rain events followed a relatively consistent and repeatable pattern throughout the summer and into the fall at the Colorado site (e.g. Fig. S7). Immediately upon arrival of rain, FBAP concentrations increased and corresponding size distributions shifted from peaking at $3-4 \mu \mathrm{m}$ to $\sim 2.0 \mu \mathrm{m}$. Subsequent pulses of rain each resulted in $N_{\mathrm{F}, \mathrm{c}}$ increases. Several hours $(\sim 8)$ after the rain, however, a second mode peaking at $4.5 \mu \mathrm{m}$ usually became apparent and stayed elevated for $\sim 12 \mathrm{~h}$ in many cases (e.g. McCartney and Lacey, 1990). Figure 7 shows average FBAP size distributions for the Colorado site after separating into periods during rain, after rain, and without any rain influence. While this categorization is difficult due to the lack of discreet break-points between periods, and thus averages are smoothed by cross-influence, the averaged periods highlight the differing mode size and concentration behaviors. Size distributions during rain-influenced periods show a narrow peak at $2.0 \mu \mathrm{m}$ in size at higher FBAP concentration than the other two average periods shown. Afterrain periods show influence from the $\sim 2 \mu \mathrm{m}$ particles that appear during rain, but also show a high concentration of a $\sim 4 \mu$ m mode of particles with little tail. Periods without rain show a mode peaking at $4.1 \mu \mathrm{m}$, with broad width and featureless appearance, suggesting a complex mixture of particle types and sizes. Compared to periods without rain influence, the integrated $N_{\mathrm{F}, \mathrm{c}}$ increased on average by approximately factors of $\sim 5$ and $\sim 2$ during and after rain, respectively.

Rain events occurred commonly during the afternoon, and thus strongly influenced diurnal patterns (see Sect. S1.3, Fig. S8). We hypothesize that FBAP observed during rain is either being washed out of the column of air above the measurement site by falling rain drops and re-suspended when droplets hit the ground and shatter, or they are being released mechanically from plant and soil surfaces by the agitation of falling hydrometeors. We further hypothesize that the mode of particles commonly observed hours after the rain are spores being actively emitted by fungi taking advantage of moist, cool air for germination. In related studies we reported that bioparticles during the BEACHON-RoMBAS study were also observed to be highly ice active (Huffman et al., 2013; Prenni et al., 2013; Tobo et al., 2013), suggesting that such bioparticles could influence ice cloud formation if lofted sufficiently.

At the Finland site, rain was also observed to cause a sudden increase in FBAP concentration. However, in contrast to observations at the Colorado site, no after-rain effect was observed in Finland and the magnitude of $N_{\mathrm{F}, \mathrm{c}}$ increase was considerably less than in Colorado. The reason behind this may be that actively ejected fungal species present in the relatively dry Colorado forests need to react quickly to elevated $\mathrm{RH}$ after rain for ecological advantage, whereas species in more humid environments, such as the boreal forest, can be released more continuously without need for immediate fitness gain (e.g. Pinkerton et al., 1998) . The observed pattern at the Finland site was that as rain began to fall, $N_{\mathrm{F}, \mathrm{c}}$ increased sharply, but quickly returned to approximate prerain levels (Fig. S9). The predominant particle mode during dry periods peaked at $2.9 \mu \mathrm{m}$, but during rain a $2.2 \mu \mathrm{m}$ mode dominated. As with the observations in Colorado, the relationship between rain and FBAP increase was strongest in summer periods and was less consistent during other seasons.

\section{Conclusions}

Fluorescent biological aerosol particles were measured continuously in real-time at two forested sites using a UV-APS. The boreal site in Hyytiälä, Finland and the semi-arid site in the Manitou Experimental Forest, Colorado showed similar seasonal FBAP cycles, with concentrations highest during the summer $\left(0.051 \mathrm{~cm}^{-3}\right.$ and $0.030 \mathrm{~cm}^{-3}$, respectively) and lowest during winter when temperatures were the coldest. Snow cover appeared to prevent local bioaerosol emission from vegetated surfaces, highlighted by correlation of snow cover measurements with winter FBAP concentrations lower in Finland than in Colorado, where dry ground was more often free of snow. Total particle number did not follow the same trend, remaining relatively constant throughout the year at each sampling location and showing minimal diurnal periodicity. These observations suggest that the source of fluorescent bioparticles was different from that of the non-fluorescent particles that dominated the total coarse particle number and that FBAP concentrations were influenced more heavily by biological emission than by boundary layer meteorology. Previous studies have suggested that certain bioparticles nucleate ice at temperatures sufficient to influence mixed-phase cloud formation and evolution (Möhler et al., 2007), and work has been done recently to globally model bioparticle effects on clouds (Hoose et al., 2010; Sesartic et al., 2012; Burrows et al., 2013). The strong cycles of FBAP observed here suggest that such parameterizations of bioparticle concentrations need both seasonal and daily temporal elements.

The FBAP at each site discussed here exhibited distinct trends, but was most concentrated between 1.5 and $6 \mu \mathrm{m}$ in particle size, as has been reported previously. At the Finland 

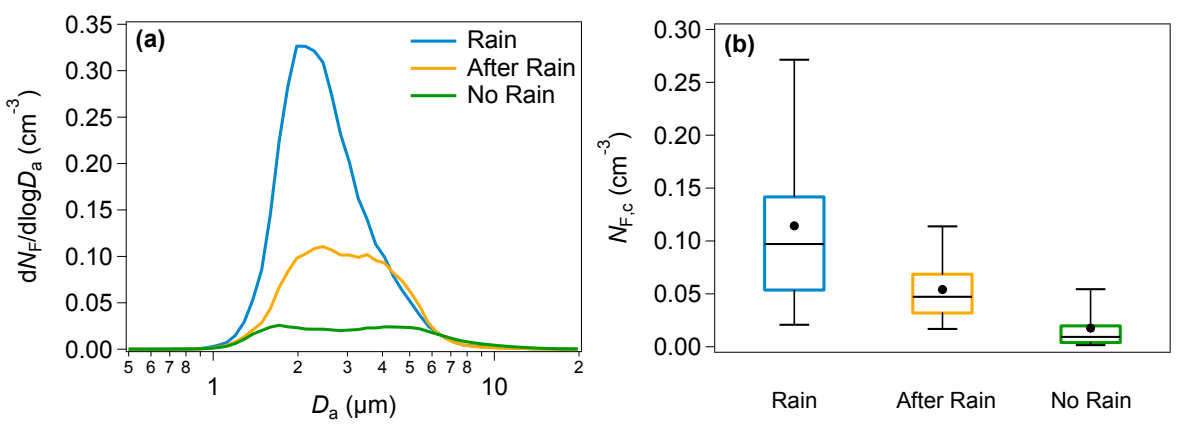

Fig. 7. Summer average rain influence in Colorado. (a) Mean size distributions of $N_{\mathrm{F}}$ concentration. (b) Whisker plots showing $N_{\mathrm{F}, \mathrm{c}}$ concentration. Whisker plots represent mean and median values (black dots, red lines, respectively), 25th and 75th percentiles (boxes), 5th and 95th percentiles (vertical lines).

site three FBAP modes were commonly observed, at $\sim 1.5$, $\sim 3$, and $\sim 5 \mu \mathrm{m}$, with additional particles observed below the $1 \mu \mathrm{m}$ considered here as the instrument cut-off. The 2.5$3.0 \mu \mathrm{m}$ mode was nearly ubiquitous and often extremely narrow in width. This mode dominated the FBAP size distributions during spring, summer, and fall, but during the winter season the FBAP number distribution shifted to peak at $\sim 1.5 \mu \mathrm{m}$. The appearance and disappearance of most individual particle modes were not obviously explainable by changes in wind speed or wind direction, suggesting that particle sources were either not local in nature, or came from multiple nearby point sources. In contrast to the Finland site, FBAP number distributions at the Colorado site were dominated by modes at $1.5 \mu \mathrm{m}$ and $5.0 \mu \mathrm{m}$ throughout the observed seasons. Both sites also show the same daily trends as have been reported previously (Huffman et al., 2012; Toprak and Schnaiter, 2013), with FBAP concentrations generally following RH patterns of daily maxima during the late night and early morning and minima during the day. Hourly particle size distributions were considerably broader at the Colorado site than at the Finland site, however.

Air temperature, relative humidity and precipitation were observed to correlate strongly with FBAP concentrations at both sites. As viewed on a yearly or seasonal basis, higher temperatures were correlated with higher bioparticle concentrations, which is likely to reflect an increase of biological activity and bioparticle release with ambient temperature. On a daily basis, however, FBAP was generally lowest during the day when temperatures were highest and when relative humidities were lowest, as discussed below. We observed much lower FBAP concentrations during winter and when averaged seasonally, a minimum temperature of 0 or $-5^{\circ} \mathrm{C}$ was necessary at the Finland and Colorado sites, respectively, to initiate seasonal FBAP increase.

Relative humidity was also shown to correlate with FBAP concentration. During winter at both sites the increase of FBAP with RH was minimal due to the low temperatures, snow cover, and reduced biological activity. As with temperature, elucidating trends of the RH and FBAP relationship from seasonal averages is not always clear. During spring, summer, and fall at each site, FBAP increased with RH during the day, but did not necessarily correlate similarly as a season average. During summer at the Finland site, however, there was a clear, consistent FBAP increase with increasing $\mathrm{RH}$, up to an RH value of $82 \%$, above which the FBAP concentration dropped steeply. We hypothesize that during the summer, increased RH at night triggers the active wet discharge of bioparticles such as fungal spores, but that this release is hindered by the formation of dew when the ambient temperature gets close to the dew point temperature. During the summer at the Colorado site, however, this effect was not observed, and FBAP increased steadily with RH.

Rain also played a significant role, influencing FBAP concentrations at both sites. During summer and fall at the Colorado site, the rain caused a sharp spike in concentration of FBAP, peaking at $2.0 \mu \mathrm{m}$, that scaled with rain intensity and lasted minutes to hours. The relative increase of these particles overwhelmed even the total coarse particle concentration, which increased by a factor of 5-20 during rain. We suggest that rain causes an increase in FBAP by releasing bioparticles from the ground via some splash-based mechanism that ejects terrestrial spores and bioparticles (e.g. Faulwetter, 1917; Butterworth and McCartney, 1991; Madden, 1997; Huber et al., 1998; Morris et al., 2011). Several hours after the rain a particle mode peaking at $4.5 \mu \mathrm{m}$ consistently became present and remained elevated for up to twelve hours, while bioparticles of all other sizes dissipated. The pattern was repeatable during rain events through the summer and into the fall. At the Finland site we observed a similar increase of FBAP at $2 \mu \mathrm{m}$ during rain. The relative increase during rain at the Finland site was weaker than at the Colorado site, however, with no after-rain period. Additionally, the concentration of the dominant $3 \mu \mathrm{m}$ mode usually present before rain was reduced.

Overall, the long-term measurement results reported in this study confirm that the emission and abundance of biological aerosol particles in forest air are closely linked to meteorological conditions. They are consistent with earlier studies 
suggesting a tight coupling between biological aerosols and the hydrological cycle, which may have an influence on the formation and properties of clouds and precipitation, and thus on regional and global climate.

\section{Supplementary material related to this article is available online at http://www.atmos-chem-phys.net/13/ 11987/2013/acp-13-11987-2013-supplement.pdf.}

Acknowledgements. The study was financially supported by: the Max Planck Society (MPG) and the Max Planck Graduate Center with the Johannes Gutenberg University Mainz (MPGC), the LEC Geocycles Mainz, EUSAAR project FluBioNEF, and internal faculty funding from the University of Denver. The authors thank J. Levula for logistical and technical support at the Finland site; the USFS, NCAR, R. Oakes, A. Guenther, J. Smith, and J. Ortega for logistical and technical support at the Manitou Experimental Forest field site; J. Jimenez and D. Day for organizational support for the BEACHON-RoMBAS campaign; A. Turnipseed and D. Gochis for meteorological data at the Colorado site; and M. O. Andreae for support at the MPI for Chemistry. Support from the Academy of Finland (Finnish centre of excellence 141135) and the European Research Council (ATMNUCLE) is gratefully acknowledged.

Edited by: R. Holzinger

\section{References}

Aizawa, T. and Kosaka, H.: Investigation of early soot formation process in a diesel spray flame via excitation-emission matrix using a multi-wavelength laser source, Int. J. Engine Res., 9, 7997, 2008.

Allitt, U.: Airborne fungal spores and the thunderstorms of 24 June 1994, Aerobiologia, 16, 397-406, 2000.

Bones, D. L., Henricksen, D. K., Mang, S. A., Gonsior, M., Bateman, A. P., Nguyen, T. B., Cooper, W. J., and Nizkorodov, S. A.: Appearance of strong absorbers and fluorophores in limonene$\mathrm{O}_{3}$ secondary organic aerosol due to $\mathrm{NH}_{4}^{+}$-mediated chemical aging over long time scales, J. Geophys. Res.-Atmos., 115, D05203, doi:10.1029/2009jd012864, 2010.

Brosseau, L. M., Vesley, D., Rice, N., Goodell, K., Nellis, M., and Hairston, P.: Differences in detected fluorescence among several bacterial species measured with a direct-reading particle sizer and fluorescence detector, Aerosol Sci. Tech., 32, 545-558, 2000.

Burch, M. and Levetin, E.: Effects of meteorological conditions on spore plumes, Int. J. Biometeorol., 46, 107-117, doi:10.1007/s00484-002-0127-1, 2002.

Burrows, S. M., Elbert, W., Lawrence, M. G., and Pöschl, U.: Bacteria in the global atmosphere - Part 1: Review and synthesis of literature data for different ecosystems, Atmos. Chem. Phys., 9, 9263-9280, doi:10.5194/acp-9-9263-2009, 2009a.

Burrows, S. M., Butler, T., Jöckel, P., Tost, H., Kerkweg, A., Pöschl, U., and Lawrence, M. G.: Bacteria in the global atmosphere - Part 2: Modeling of emissions and transport be- tween different ecosystems, Atmos. Chem. Phys., 9, 9281-9297, doi:10.5194/acp-9-9281-2009, 2009b.

Burrows, S. M., Hoose, C., Pöschl, U., and Lawrence, M. G.: Ice nuclei in marine air: biogenic particles or dust?, Atmos. Chem. Phys., 13, 245-267, doi:10.5194/acp-13-245-2013, 2013.

Butterworth, J. and McCartney, H. A.: The dispersal of bacteria from leaf surfaces by water splash, J. Appl. Bacteriol., 71, 484496, 1991.

Crawford, I., Robinson, N. H., Flynn, M. J., Foot, V. E., Gallagher, M. W., Huffman, J. A., Stanley, W. R., and Kaye, P. H.: Characterisation of Bioaerosol Emissions from a Colorado Pine Forest: Results from the BEACHON-RoMBAS Experiment, Atmos. Chem. Phys. Discuss., submitted, 2013.

Christner, B. C., Morris, C. E., Foreman, C. M., Cai, R. M., and Sands, D. C.: Ubiquity of biological ice nucleators in snowfall, Science, 319, 1214-1214, doi:10.1126/science.1149757, 2008.

Constantinidou, H. A., Hirano, S. S., Baker, L. S., and Upper, C. D.: Atmospheric dispersal of ice nucleation-active bacteria - the role of rain, Phytopathology, 80, 934-937, doi:10.1094/Phyto80-934, 1990.

Dal Maso, M., Kulmala, M., Riipinen, I., Wagner, R., Hussein, T., Aalto, P., and Lehtinen, K. E. J.: Formation and growth of fresh atmospheric aerosols: eight years of aerosol size distribution data from SMEAR II, Hyytiälä, Finland, Boreal Environ. Res., 10, 323-336, 2005.

Dal Maso, M., Hari, P., and Kulmala, M.: Spring recovery of photosynthesis and atmospheric particle formation, Boreal Environ. Res., 14, 711-721, 2009.

De Groot, R. C.: Diurnal cycles of airborne spores produced by forest fungi, Phytopathology, 58, 1223-1229, 1968.

DeLeon-Rodriguez, N., Lathem, T. L., Rodriguez-R, L. M., Barazesh, J. M., Anderson, B. E., Beyersdorf, A. J., Ziemba, L. D., Bergin, M., Nenes, A., and Konstantinidis, K. T.: Microbiome of the upper troposphere: Species composition and prevalence, effects of tropical storms, and atmospheric implications, P. Natl. Acad. Sci., 110, 2575-2580, doi:10.1073/pnas.1212089110, 2013.

DeMott, P. J., Prenni, A. J., Liu, X., Kreidenweis, S. M., Petters, M. D., Twohy, C. H., Richardson, M. S., Eidhammer, T., and Rogers, D. C.: Predicting global atmospheric ice nuclei distributions and their impacts on climate, Proc. Natl. Acad. Sci., 107, 11217-11222, doi:10.1073/pnas.0910818107, 2010.

Després, V. R., Huffman, J. A., Burrows, S. M., Hoose, C., Safatov, A. S., Buryak, G. A., Fröhlich-Nowoisky, J., Elbert, W., Andreae, M. O., Pöschl, U., and Jaenicke, R.: Primary Biological Aerosol Particles in the Atmosphere: A Review, Tellus B, 64, 15598, doi:10.3402/tellusb.v64i0.15598, 2012.

DiGangi, J. P., Boyle, E. S., Karl, T., Harley, P., Turnipseed, A., Kim, S., Cantrell, C., Maudlin III, R. L., Zheng, W., Flocke, F., Hall, S. R., Ullmann, K., Nakashima, Y., Paul, J. B., Wolfe, G. M., Desai, A. R., Kajii, Y., Guenther, A., and Keutsch, F. N.: First direct measurements of formaldehyde flux via eddy covariance: implications for missing in-canopy formaldehyde sources, Atmos. Chem. Phys., 11, 10565-10578, doi:10.5194/acp-1110565-2011, 2011.

Elbert, W., Taylor, P. E., Andreae, M. O., and Pöschl, U.: Contribution of fungi to primary biogenic aerosols in the atmosphere: wet and dry discharged spores, carbohydrates, and inorganic ions, At- 
mos. Chem. Phys., 7, 4569-4588, doi:10.5194/acp-7-4569-2007, 2007.

Eng, J., Lynch, R. M., and Balaban, R. S.: Nicotinamide Adenine Dinucleotide Fluorescence Spectroscopy and Imaging of Isolated Cardiac Myocytes, Biophys. J., 55, 621-630, 1989.

Faulwetter, R. C.: Wind-blown rain, a factor in disease dissemination, J. Agric. Res., 10, 639-648, 1917.

Fitt, B. D. L., McCartney, H. A., and Walklate, P. J.: The Role of Rain in Dispersal of Pathogen Inoculum, Annu. Rev. Phytopathol., 27, 241-270, 1989.

Franze, T., Weller, M. G., Niessner, R., and Pöschl, U.: Protein nitration by polluted air, Environ. Sci. Technol., 39, 1673-1678, doi:10.1021/es0488737, 2005.

Fröhlich-Nowoisky, J., Pickersgill, D. A., Després, V. R., and Pöschl, U.: High diversity of fungi in air particulate matter, Proc. Natl. Acad. Sci., 106, 12814-12819, doi:10.1073/pnas.0811003106, 2009.

Fröhlich-Nowoisky, J., Burrows, S. M., Xie, Z., Engling, G., Solomon, P. A., Fraser, M. P., Mayol-Bracero, O. L., Artaxo, P., Begerow, D., Conrad, R., Andreae, M. O., Després, V. R., and Pöschl, U.: Biogeography in the air: fungal diversity over land and oceans, Biogeosciences, 9, 1125-1136, doi:10.5194/bg9-1125-2012, 2012.

Gabey, A. M., Gallagher, M. W., Whitehead, J., Dorsey, J. R., Kaye, P. H., and Stanley, W. R.: Measurements and comparison of primary biological aerosol above and below a tropical forest canopy using a dual channel fluorescence spectrometer, Atmos. Chem. Phys., 10, 4453-4466, doi:10.5194/acp-10-4453-2010, 2010.

Gabey, A. M., Stanley, W. R., Gallagher, M. W., and Kaye, P. H.: The fluorescence properties of aerosol larger than $0.8 \mu \mathrm{m}$ in urban and tropical rainforest locations, Atmos. Chem. Phys., 11, 5491-5504, doi:10.5194/acp-11-5491-2011, 2011.

Gabey, A. M., Vaitilingom, M., Freney, E., Boulon, J., Sellegri, K., Gallagher, M. W., Crawford, I. P., Robinson, N. H., Stanley, W. R., and Kaye, P. H.: Observations of fluorescent and biological aerosol at a high-altitude site in central France, Atmos. Chem. Phys., 13, 7415-7428, doi:10.5194/acp-13-7415-2013, 2013.

Gilbert, G. S.: Nocturnal fungi: Airborne spores in the canopy and understory of a tropical rain forest, Biotropica, 37, 462-464, doi:10.1111/j.1744-7429.2005.00061.x, 2005.

Gottwald, T. R., Trocine, T. M., and Timmer, L. W.: A computercontrolled environmental chamber for the study of aerial fungal spore release, Phytopathology, 87, 1078-1084, 1997.

Gregory, P. H. and Hirst, J. M.: The summer air-spora at Rothamsted in 1952, J. Gen. Microbiol., 17, 135-152, 1957.

Griffin, D. W., Kubilay, N., Kocak, M., Gray, M. A., Borden, T. C., and Shinn, E. A.: Airborne desert dust and aeromicrobiology over the Turkish Mediterranean coastline, Atmos, Environ,, 41, 4050-4062, doi:10.1016/j.atmosenv.2007.01.023, 2007.

Hairston, P. P., Ho, J., and Quant, F. R.: Design of an instrument for real-time detection of bioaerosols using simultaneous measurement of particle aerodynamic size and intrinsic fluorescence, J, Aerosol Sci,, 28, 471-482, 1997.

Hallar, A. G., Chirokova, G., McCubbin, I., Painter, T. H., Wiedinmyer, C., and Dodson, C.: Atmospheric bioaerosols transported via dust storms in the western United States, Geophys. Res. Lett., 38, L17801, doi:10.1029/2011g1048166, 2011.
Hari, P. and Kulmala, M.: Stations for Meausring EcosystemAtmosphere Relations (SMEAR II), Boreal Environ. Res., 10, 315-322, 2005.

Hill, S. C., Mayo, M. W., and Chang, R. K.: Fluorescence of bacteria, pollens, and naturally occurring airborne particles: excitation/emission spectra, Army Research Laboratory report ARLTR-4722, 2009.

Hirst, J. M. and Stedman, O. J.: Dry liberation of fungus spores by raindrops, Jo. Gen. Microbiol., 33, 335-344, 1963.

Hoose, C., Kristjansson, J. E., and Burrows, S. M.: How important is biological ice nucleation in clouds on a global scale?, Environ. Res. Lett., 5, 024009, doi:10.1088/1748-9326/5/2/024009, 2010.

Huber, L., Madden, L. V., and Fitt, B. D. L.: Rain-splash and spore dispersal: a physical prespective, The Epidemiology of Plant Diseases, 348-370, 1998.

Huffman, J. A., Treutlein, B., and Pöschl, U.: Fluorescent biological aerosol particle concentrations and size distributions measured with an Ultraviolet Aerodynamic Particle Sizer (UVAPS) in Central Europe, Atmos. Chem. Phys., 10, 3215-3233, doi:10.5194/acp-10-3215-2010, 2010.

Huffman, J. A., Sinha, B., Garland, R. M., Snee-Pollmann, A., Gunthe, S. S., Artaxo, P., Martin, S. T., Andreae, M. O., and Pöschl, U.: Size distributions and temporal variations of biological aerosol particles in the Amazon rainforest characterized by microscopy and real-time UV-APS fluorescence techniques during AMAZE-08, Atmos. Chem. Phys., 12, 11997-12019, doi:10.5194/acp-12-11997-2012, 2012.

Huffman, J. A., Prenni, A. J., DeMott, P. J., Pöhlker, C., Mason, R. H., Robinson, N. H., Fröhlich-Nowoisky, J., Tobo, Y., Després, V. R., Garcia, E., Gochis, D. J., Harris, E., Müller-Germann, I., Ruzene, C., Schmer, B., Sinha, B., Day, D. A., Andreae, M. O., Jimenez, J. L., Gallagher, M., Kreidenweis, S. M., Bertram, A. K., and Pöschl, U.: High concentrations of biological aerosol particles and ice nuclei during and after rain, Atmos. Chem. Phys., 13, 6151-6164, doi:10.5194/acp-13-6151-2013, 2013.

Hussein, T., Norros, V., Hakala, J., Petäjä, T., Aalto, P. P., Rannik, U., Vesala, T., and Ovaskainen, O.: Species traits and inertial deposition of fungal spores, Aerosol Sci., 61, 81-98, 2013.

Ingold, C. T.: Active liberation of reproductive units in terrestrial fungi, Mycologist, 13, 113-116, 1999.

Jones, A. M. and Harrison, R. M.: The effects of meteorological factors on atmospheric bioaerosol concentrations - a review, Sci. Total Environ., 326, 151-180, doi:10.1016/j.scitotenv.2003.11.021, 2004.

Kaarakainen, P., Meklin, T., Rintala, H., Hyvärinen, A., Kärkkäinen, P., Vepsäläinen, A., Hirvonen, M.-R., and Nevalainen, A.: Seasonal Variation in Airborne Microbial Concentrations and Diversity at Landfill, Urban and Rural Sites, CLEAN - Soil Air Water, 36, 556-563, doi:10.1002/clen.200700179, 2008.

Kaye, P. H., Stanley, W. R., Hirst, E., Foot, E. V., Baxter, K. L., and Barrington, S. J.: Single particle multichannel bio-aerosol fluorescence sensor, Opt. Express, 13, 3583-3593, 2005.

Laakso, L., Grönholm, T., Rannik, Ü., Kosmale, M., Fiedler, V., Vehkamäki, H., and Kulmala, M.: Ultrafine particle scavenging coefficients calculated from 6 years field measurements, Atmos. Environ., 37, 3605-3613, 2003.

Lee, H. J., Laskin, A., Laskin, J., and Nizkorodov, S. A.: ExcitationEmission Spectra and Fluorescence Quantum Yields for Fresh 
and Aged Biogenic Secondary Organic Aerosols, Environ. Sci. Technol., 47, 5763-5770, doi:10.1021/es400644c, 2013.

Madden, L. V.: Effects of rain on splash dispersal of fungal pathogens, Can. J. Plant Pathol., 19, 225-230, 1997.

Mäkinen, Y. and Ollikainen, P.: Diurnal and Seasonal Variations in the Airspora Composition in Turku, S. Finland, Bulletins from the Ecological Research Committee, Scandinavian Aerobiology, 18, pp. 143-152, 1973.

Manninen, H. E., Sihto-Nissilä, S.-L., Huffman, J. A., Bäck, J., Pessi, A.-M., Hiltunen, V., Aalto, P., Hidalgo, P. J., Hari, P., Saarto, A., Kulmala, M., and Petäjä, T.: Annual pattern of airborne pollen grains, fungal spores and particle mass in a boreal forest, Boreal Environ. Res., submitted, 2013.

Matthias-Maser, S., Obolkin, V., Khodzer, T., and Jaenicke, R.: Seasonal variation of primary biological aerosol particles in the remote continental region of Lake Baikal/Siberia, Atmos. Environ., 34, 3805-3811, doi:10.1016/s1352-2310(00)00139-4, 2000.

McCartney, H. A. and Lacey, M. E.: The Production and Release of Ascospores in Pyrenopeziza-Brassicae on Oilseed Rape, Plant Pathol., 39, 17-32, 1990.

Möhler, O., DeMott, P. J., Vali, G., and Levin, Z.: Microbiology and atmospheric processes: the role of biological particles in cloud physics, Biogeosciences, 4, 1059-1071, doi:10.5194/bg-4-10592007, 2007.

Morris, C. E., Georgakopoulos, D. G., and Sands, D. C.: Ice nucleation active bacteria and their potential role in precipitation, J. Phys. IV, 121, 87-103, doi:10.1051/jp4:2004121004, 2004.

Morris, C. E., Sands, D. C., Vinatzer, B. A., Glaux, C., Guilbaud, C., Buffiere, A., Yan, S., Dominguez, H., and Thompson, B. M.: The life history of the plant pathogen Pseudomonas syringae is linked to the water cycle, ISME J., 2, 321-334, 2008.

Morris, C. E., Sands, D. C., Bardin, M., Jaenicke, R., Vogel, B., Leyronas, C., Ariya, P. A., and Psenner, R.: Microbiology and atmospheric processes: research challenges concerning the impact of airborne micro-organisms on the atmosphere and climate, Biogeosciences, 8, 17-25, doi:10.5194/bg-8-17-2011, 2011.

Morris, C. E., Conen, F., Huffman, J. A., Phillips, V., Pöschl, U., and Sands, D. C.: Bioprecipitation: A feedback cycle linking Earth history, ecosystem dynamics and land use through biological ice nucleators in the atmosphere, Glob. Change Biol., doi:10.1111/gcb.12447, 2013.

O’Connor, D. J., Iacopino, D., Healy, D. A., O’Sullivan, D., and Sodeau, J. R.: The intrinsic fluorescence spectra of selected pollen and fungal spores, Atmos. Environ., 45, 6451-6458, doi:10.1016/j.atmosenv.2011.07.044, 2011.

Ortega, J., Turnipseed, A., Smith, J. N., Guenther, A. B., Karl, T. G., Day, D. A., Gochis, D., Huffman, J. A., Prenni, A. J., Levin, E. J. T., Kreidenweis, S. M., DeMott, P. J., Tobo, Y., Patton, E. G., Hodzic, A., Cui, Y., Harley, P. C., Hornbrook, R. S., Apel, E. C., Monson, R. K., Eller, A. S. D., Greenberg, J. P., Barth, M., Campuzano-Jost, P., Palm, B. B., Jimenez, J. L., Aiken, A. C., Dubey, M. K., Geron, C., Offenberg, J., Ryan, M. G., Fornwalt, P. J., Pryor, S. C., Keutsch, F. N., DiGangi, J. P., Chan, A. W. H., Goldstein, A. H., Wolfe, G. M., Kim, S., Kaser, L., Schnitzhofer, R., and Hansel, A.: Manitou Experimental Forest Observatory: A semi-arid, forested site for studying ecosystem-atmosphere interactions, Atmos. Chem. Phys. Discuss., submitted, 2013.

Pan, Y.-L., Hill, S. C., Pinnick, R. G., House, J. M., Flagan, R. C., and Chang, R. K.: Dual-excitation-wavelength fluorescence spectra and elastic scattering for differentiation of single airborne pollen and fungal particles, Atmos. Environ., 45, 1555-1563, doi:10.1016/j.atmosenv.2010.12.042, 2011.

Paul, P. A., El-Allaf, S. M., Lipps, P. E., and Madden, L. V.: Rain splash dispersal of Gibberellazeae within wheat canopies in Ohio, Phytopathology, 94, 1342-1349, 2004.

Pinkerton, J. N., Johnson, K. B., Stone, J. K., and Ivors, K. L.: Factors affecting the release of ascospores of anisogramma anomala, Phytopathology, 88, 122-128, 1998.

Pöhlker, C., Huffman, J. A., and Pöschl, U.: Autofluorescence of atmospheric bioaerosols - fluorescent biomolecules and potential interferences, Atmos. Meas. Tech., 5, 37-71, doi:10.5194/amt-537-2012, 2012.

Pöhlker, C., Huffman, J. A., Förster, J.-D., and Pöschl, U.: Autofluorescence of atmospheric bioaerosols: spectral fingerprints and taxonomic trends of pollen, Atmos. Meas. Tech., 6, 3369-3392, doi:10.5194/amt-6-3369-2013, 2013.

Polymenakou, P. N., Mandalakis, M., Stephanou, E. G., and Tselepides, A.: Particle size distribution of airborne microorganisms and pathogens during an intense African dust event in the eastern Mediterranean, Environ. Health Persp., 116, 292-296, doi:10.1289/ehp.10684, 2008.

Pöschl, U.: Atmospheric aerosols: composition, transformation, climate and health effects, Angewandte Chemie, International Edition 44, 7520-7540, 2005.

Pöschl, U., Martin, S. T., Sinha, B., Chen, Q., Gunthe, S. S., Huffman, J. A., Borrmann, S., Farmer, D. K., Garland, R. M., Helas, G., Jimeney, J. L., King, S. M., Manzi, A., Mikhailov, E., Pauliquevis, T., Petters, M. D., Prenni, A. J., Roldin, P., Rose, D., Schneider, J., Su, H., Zorn, S. R., Artaxo, P., and Andreae, M. O.: Rainforest Aerosols as Biogenic Nuclei of Clouds and Precipitation in the Amazon, Science, 329, 15131516, doi:10.1126/science.1191056, 2010.

Pratt, K. A., DeMott, P. J., French, J. R., Wang, Z., Westphal, D. L., Heymsfield, A. J., Twohy, C. H., Prenni, A. J., and Prather, K. A.: In situ detection of biological particles in cloud ice-crystals, Nat. Geosci., 2, 397-400, doi:10.1038/ngeo521, 2009.

Prenni, A. J., Petters, M. D., Kreidenweis, S. M., Heald, C. L., Martin, S. T., Artaxo, P., Garland, R. M., Wollny, A. G., and Pöschl, U.: Relative roles of biogenic emissions and Saharan dust as ice nuclei in the Amazon basin, Nat. Geosci., 2, 402-405, doi:10.1038/ngeo517, 2009.

Prenni, A. J., Tobo, Y., Garcia, E., DeMott, P. J., Huffman, J. A., McCluskey, C. S., Kreidenweis, S. M., Prenni, J. E., Pöhlker, C., and Pöschl, U.: The impact of rain on ice nuclei populations at a forested site in Colorado, Geophys. Res. Lett., 40, 227-231, doi:10.1029/2012g1053953, 2013.

Pringle, A., Patek, S. N., Fischer, M., Stolze, J., and Money, N. P.: The captured launch of a ballistospore, Mycologia, 97, 866-871, 2005.

Robinson, N. H., Allan, J. D., Huffman, J. A., Kaye, P. H., Foot, V. E., and Gallagher, M.: Cluster analysis of WIBS single-particle bioaerosol data, Atmos. Meas. Tech., 6, 337-347, doi:10.5194/amt-6-337-2013, 2013.

Roshchina, V. V.: Autofluorescence of plant secreting cells as a biosensor and bioindicator reaction, J. Fluoresc., 13, 403-420, 2003.

Santarpia, J. L., Ratnesar-Shumate, S., Gilberry, J. U., and Quizon, J. J.: Relationship Between Biologically Fluorescent Aerosol and 
Local Meteorological Conditions, Aerosol Sci. Tech., 47, 655661, doi:10.1080/02786826.2013.781263, 2013.

Sesartic, A., Lohmann, U., and Storelvmo, T.: Bacteria in the ECHAM5-HAM global climate model, Atmos. Chem. Phys., 12, 8645-8661, doi:10.5194/acp-12-8645-2012, 2012.

Sivaprakasam, V., Pletcher, T., Tucker, J. E., Huston, A. L., McGinn, J., Keller, D., and Eversole, J. D.: Classification and selective collection of individual aerosol particles using laser-induced fluorescence, Appl. Optics, 48, B126-B136, 2009.

Tack, A. J. M., Hakala, J., Petäjä, T., Kulmala, M., and Laine, A. L.: Genotype and spatial structure shape pathogen dispersal and disease dynamics at small spatial scales, Ecology, doi:10.1890/13$0518.1,2013$.

Tobo, Y., Prenni, A. J., DeMott, P. J., Huffman, J. A., McCluskey, C. S., Tian, G., Pöhlker, C., Pöschl, U., and Kreidenweis, S. M.: Biological aerosol particles as a key determinant of ice nuclei populations in a forest ecosystem, J. Geophys. Res.-Atmos., 118, 10100-10110, doi:10.1002/jgrd.50801, 2013.
Toprak, E. and Schnaiter, M.: Fluorescent biological aerosol particles measured with the Waveband Integrated Bioaerosol Sensor WIBS-4: laboratory tests combined with a one year field study, Atmos. Chem. Phys., 13, 225-243, doi:10.5194/acp-13225-2013, 2013.

Trenberth, K. E.: What are the seasons?, Department of Atmospheric Sciences, University of Illinois at Urbana-Champaign, Urbana, 7 pp., 1983.

Womack, A. M., Bohannan, B. J. M., and Green, J. L.: Biodiversity and biogeography of the atmosphere, Philos. T. R. Soc. B, 365, 3645-3653, 10.1098/rstb.2010.0283, 2010.

$\mathrm{Wu}, \mathrm{C} . \mathrm{H}$. and Warren, H. L.: Induced autofluorescence in fungi and its correlation with viability-Potential applications of fluorescence microscopy, Phytopathology, 74, 1353-1358, 1984a.

Wu, C. H. and Warren, H. L.: Natural autofluoresence in fungi, and its correlation with viability, Mycologia, 76, 1049-1058, 1984b. 